Original Article

\title{
Comparative analysis of brain in relation to the body length and weight of common carp (Cyprinus carpio) in captive (hatchery) and wild (river system) populations
}

\author{
Análise comparativa do cérebro em relação ao comprimento do corpo e peso da \\ carpa comum (Cyprinus carpio) em populações de cativeiro (incubatório) e selvagem \\ (sistema fluvial)
}

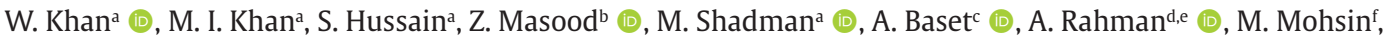 \\ S. Alfarrajg (1) \\ a University of Malakand, Department of Zoology, Lower Dir, Pakistan. \\ bSardar Bahadur Khan Women University, Department of Zoology, Quetta, Pakistan. \\ ' Bacha Khan University, Department of Zoology, Charsadda, Pakistan. \\ ${ }^{\mathrm{d}}$ Friedrich-Alexander-University - FAU, Institute of Geography, Department of Geography and Geosciences, Erlangen- Nuremberg Germany. \\ 'University of Malakand, Department of Botany, Chakdara, Dir Lower, Pakistan. \\ ${ }^{\mathrm{f}}$ Islamia College University, Department of Zoology, Peshawar, Pakistan. \\ ${ }^{g}$ King Saud University, College of Science, Zoology Department, Riyadh, Saudi Arabia.
}

\begin{abstract}
Cyprinus carpio is the member of family cyprinidae commonly called common carp. This study was aimed to find out the comparison of brain of wild (river system) and captive (hatchery reared) population of common carp. A total of thirty samples ( 15 from hatchery and 15 from river Swat) were collected. All the specimens were examined in Laboratory of Parasitoloy, Zoology Department, University of Malakand. Findings indicated that wild population were greater in brain size and weight as compared to hatchery reared population. The fish samples collected from captive environment (hatchery) were showing more weight and length as compared to wild population of common carps. The mean value of total weight of hatchery fishes $345 \pm 48.68$ and the mean value of brain weight of hatchery reared fishes $0.28 \pm 0.047$. The mean value of wild fish's total body weight $195.16 \pm 52.58$ and the mean value of brain weight of wild fishes are $0.45 \pm 0.14$. Present research calls for the fact that fish in dependent environmental conditions possess brain larger in size as compared to its captive population, it is due to use and disuse of brain in their environmental requirements.
\end{abstract}

Keywords: brain size, common carp, river Swat, hatchery, wild fishes.

\begin{abstract}
Resumo
Cyprinus carpio é o membro da família cyprinidae comumente chamada de carpa comum. O objetivo deste estudo foi comparar a população de cérebros de carpa comum selvagem (sistema fluvial) e em cativeiro (criação em incubatório). Um total de trinta amostras (15 do incubatório e 15 do rio Swat) foram coletadas. Todos os espécimes foram examinados no Laboratório de Parasitoloy, Departamento de Zoologia da Universidade de Malakand. Os resultados indicaram que a população selvagem era maior em tamanho e peso do cérebro em comparação com a população criada em incubatório. As amostras de peixes coletadas em ambiente de cativeiro (incubatório) estavam apresentando mais peso e comprimento em comparação com a população selvagem de carpas comuns. $O$ valor médio do peso total dos peixes de incubação $345 \pm 48$,68 e o valor médio do peso do cérebro de peixes criados em incubadoras $0,28 \pm 0,047$. O valor médio do peso corporal total dos peixes selvagens $195,16 \pm 52,58$ e o valor médio do peso do cérebro dos peixes selvagens são $0,45 \pm 0,14$. A presente pesquisa apela para o fato de que peixes em condições ambientais dependentes possuem cérebros maiores em tamanho em comparação com sua população em cativeiro, isso se deve ao uso e desuso do cérebro em suas necessidades ambientais.
\end{abstract}

Palavras-chave: tamanho do cérebro, carpa comum, rio Swat, incubatório, peixes selvagens.

*e-mail: walikhan.pk@gmail.com

Received: August 28, 2020 - Accepted: October 30, 2020 


\section{Introduction}

Cyprinus carpio Linnaeus, 1758 has been remained one of the oldest domesticated fish species. This fish lives in middle and lower stretches of rivers and shallow waters. Its chemical nature represents best growth at $23-30 C^{\circ}, 5 \%$ of salinity is tolerated, $6.5-9.0 \mathrm{pH}$; oxygen concentration (0.3-0.5 mg) as well as super saturation (Crespi and New, 2009). Cyprinus carpio is widely prevalent in freshwaters as in lakes and rivers of Europe and Asia. The native wild populations are considered vulnerable to extinction IUCN but the species has also been introduced into environment worldwide, and is often considered a destructive invasive species being included in the list of the world 100 worst invasive species. The common carp is native to Europe and Asia, and has been introduced to every part of world except the poles (Crespi and New, 2009).

Common carp was first introduced in 1964 from Thailand for aquaculture in Pakistan. Owing to its great tolerance to temperature, turbidity and productive pond breeding habit, it was recognized promptly in utmost natural inland waters, including rivers, lakes, streams, canals, wetlands and even village ponds of the country. While Cyprinus carpio is common food fish in cyprinid species in inland waters and important food fish in Pakistan (Khan et al., 2016).

Fishes of fresh waters and marine waters are in risk and its population is reducing. Artificial methods of fish production in the form of hatchery have been increased in last 10 to 15 years and thus it's a vital business worldwide (Khan et al, 2011). But there are still schools of thought who believe that hatcheries practice as an alternative to wild is not good practice. Because hatcheries fishes cannot sustain natural environment thus hatcheries environment made them susceptible (Brannon, 1993).

Many researchers have been reported that the difference in brain structure effects by the environment (Masai et al., 1983; Brandstätter and Kotrschal, 1990; Kotrschal and Palzenberger, 1992; Ebinger and Rohrs, 1995; Kotrschal et al., 1998). Keeping in view the opinion of the researchers in these reports, variation in nurturing condition of fishes are present livening natural environment and captive condition (hatcheries). For example, Cyprinus carpio reproduces in the captive environments frequently shows in observable development in growth. Moreover, in anti-predator eating behaviors and sexual behaviors in different is compared to the fishes live in natural environment (Gross, 1998; Flagg et al., 2000).

It has been observed that Oncorhynchus mykiss in captive rearing environment has reduced forebrain as compare to the wild specimen, Moreover Marchetti and Nevitt's studied brain morphology around ninety-nine Oncorhynchus mykiss specimen collected from two different hatcheries and two differ wild environment (river). They revealed that standardized to body size, hatchery-reared had significantly reduced olfactory bulbs, telencephalon, and optic tectum relative to carps reared in the wild populations (Marchetti and Nevitt, 2003).

Hatcheries provide a convenient opportunity to examine whether different rearing plans impact brain growth because comparisons can be made among genetically similar fish reared in different environments. Conservation hatchery consist of conventional hatchery supplemented with some or all of the following features: automated underwater feeders, benthic substrate, in streams structure, surface cover, live food diets, increase current velocities, or predator avoidance training (Maynard et al., 2003).

Fishes reproduce in hatcheries most of the time has reduced brain size and change in behaviors as compare to the naturally reared fishes. These modification or changes in brain has been credited to changes at molecular and genetic level. These changes due to, inbreeding depression and pleiotropic effects of artificial selection for traits etc. A serious query, whether such variation in brain size are resulting from flexible responses to the nature or its due to the change in genetic makeup. It has been studied that a large reduction in brain size occurs even in the first generation of lab-reared guppies as compare to wild.

The snow trout population have been investigated for ecto and endo parasitic fauna in river Swat and river Panjkora by Khalid et al. (2020) and Ahmad et al. (2020) while there is no study on brain and its relation to the body size on any fish population in the study area. It was therefore required to address the comparison of brain of wild caught and hatchery reared common carp, relative to their body length and weight and to explore the influence of rearing environment on the development of brain structure.

\section{Materials and Methods}

\subsection{Study Area}

River Swat lies in the northern stretches of Swat, district, Pakistan. It starts in the Hindukush mountains, from where it is nourished by the glacial water throughout the years and flows through the Kalam valley in a narrow gap with a rushing speed up to Madyan and then lower plains of Swat and then go to Thana at Chakdara. In the extreme south valley, the river enters to a narrow gorge and joins the Panjkora river, at Qalangi.

\subsection{Materials used}

Chemicals and materials used in present study were formalin, recorded books, mesh net, cast net, dissection box, digital weight balance, centimeter scale, Pencil, gloves, slides, plastic bottle, iphone camera lens (20x, 4.5-90mm).

\subsection{Sample collection}

The present study was conducted from April 2018 to August 2018. For operation of the current study we have collected a total of 30 specimens including 20 from river Swat with the help of local fisher man. The local fisher men were have using cast net and electric rod while 10 samples of the common carp were collected from a local hatchery named "fish income support health program Thana Main Bypass". 


\subsection{Sample preservation}

The collected samples from wild were then preserved in plastic bottles in $10 \%$ formalin and $90 \%$ water solution, and were transferred to laboratory of center for animals Science and Fisheries, University of Malakand in laboratory the experiment was conducted within 4 days. The keys provided by Mirza and Sandhu (2007) were used for identification of fish specimens.

\subsection{Measurement of body weight}

The measurement of body weight of collected samples was done one by digital weight balance(TE214S.SARTORIUSS).

\subsection{Measurement of body length}

In current study the fish length was measured according to the general rules on the left side of fish using centimeter scale. All the samples were measured between to define points.

\subsection{Total length}

It means that length from the tip of the snout to tip up to tail.

\subsection{Dissection and extraction of brain of fish}

The collected specimen of common carp were washed with distilled water and the skulls were dissected in Parasitology Laboratory, University of Malakand. After dissection the brain were transfer in to slide the petridishes, measure by centimeter scale and weighted by using the digital balance. Heads of the collected samples were separated and were seized in an upright position for extraction of brain. All of the soft tissues of the adjacent skulls were detached. The skulls were cut with the help of sharp cutter. The bones of skulls were removed with the help of forceps because the dorsal part of the brain i.e. hind brain and mid brain would might be damaged. The dorsal part of the brain cranium was detached and exposed for further process. Then remove lateral part of the cranium by using dissecting scissor, optic nerves including other nerves of the brain stem were separate carefully without any damaging to telencephalon after that the brain from bottom side was lifted out certain samples because missing during extraction of the brain. After dissection digital iPhone camera (canon $20 \mathrm{x}, 4.5-90.0 \mathrm{~mm}$ ) was used for taking the picture as dorsal and ventral photos were have been prepared.

\section{Results}

\subsection{Morphometric measurements of common carp in captive condition}

The morphometric analysis of the six specimens of the hatchery reared fishes were included. Table 1 represents total body weight $345 \pm 48.68$ (g); total body length $33.91 \pm 2.37(\mathrm{~cm})$; total body width $7.98 \pm 1.02(\mathrm{~cm})$; head to snout length $4.91 \pm 1.03(\mathrm{~cm})$; eye to eye length $4.13 \pm 0.77(\mathrm{~cm})$; brain weight $0.28 \pm 0.047(\mathrm{~g})$. Figure 1 .

\subsection{Morphometric measurement of common carp in wild condition}

For the operation of the current study out of the total 20 specimens investigated only six fish samples were included. All the morphometric characteristics were taken in $\mathrm{cm}$ while weight is represented in gram. The morphometric analysis of the six specimens of the wild fishes were included. Table 2 represents total body weight $195.16 \pm 52.58(\mathrm{~g})$; total body length $27.78 \pm 0.89$ (cm); total body width $5.01 \pm 0.44(\mathrm{~cm})$; head to snout length $3.96 \pm 0.35(\mathrm{~cm})$; eye to eye length $2.23 \pm 0.17(\mathrm{~cm})$; brain weight $0.45 \pm 0.14(\mathrm{~g})$. Figure 2 .

\subsection{Comparison of head measurement with its brain weight of wild and captive common carps}

The obtained data of morphometric measurement in relation to brain weight were compared using their mean values (Table 3 ). The means values of wild fishes head to snout length was $3.96 \pm 0.35(\mathrm{~cm})$ less than that of captive fish specimens as $4.91 \pm 1.03(\mathrm{~cm})$. The eye to eye length of wild fishes was $2.23 \pm 0.17(\mathrm{~cm})$ less than those of captive fish species as $4.13 \pm 0.77(\mathrm{~cm})$. The brain weight of wild fishes were $0.45 \pm 0.14$ (g) greater than that of captive fish specimens $0.28 \pm 0.047(\mathrm{~g})$. Thus the total head measurement of wild fishes was found slightly less is compare to captive fishes. Similarly, the mean value of brain weight of wild fishes $0.45 \pm 0.14 \mathrm{~g}$ was slightly high is compare to captive fishes.

\subsection{Comparative analysis regarding total body length of common caps in captive and wild condition}

The obtained data of morphometric measurement of the total body length was compared using their mean values (Table 4). The mean value of wild fishes total

Table 1. Morphometric measurement of common carp in captive condition.

\begin{tabular}{|c|c|c|c|c|c|c|}
\hline Fish & TBW (g) & TBL $(\mathbf{c m})$ & TBW (cm) & HTSL (cm) & $\operatorname{ETEL}(\mathrm{cm})$ & BW (g) \\
\hline 1 & 320 & 32 & 75 & 4.3 & 3.7 & 0.27 \\
\hline 2 & 350 & 34 & 8 & 5 & 4 & 0.28 \\
\hline 3 & 290 & 32 & 7 & 4 & 3.5 & 0.25 \\
\hline 4 & 280 & 32 & 7 & 3.9 & 3.4 & 0.24 \\
\hline 5 & 400 & 36 & 9 & 6 & 5 & 0.33 \\
\hline 6 & 430 & 37.5 & 9.4 & 6.3 & 5.2 & 0.36 \\
\hline Mean & $345 \pm 48.68$ & $33.91 \pm 2.37$ & $7.98 \pm 1.02$ & $4.91 \pm 1.03$ & $4.13 \pm 0.77$ & $0.28 \pm 0.047$ \\
\hline
\end{tabular}

TBW=Total body weight, TBL=Total body length, TBW=Total body width, HTSL=Head to snout length, ETEL= Eye to eye length, BW= Brain weight 

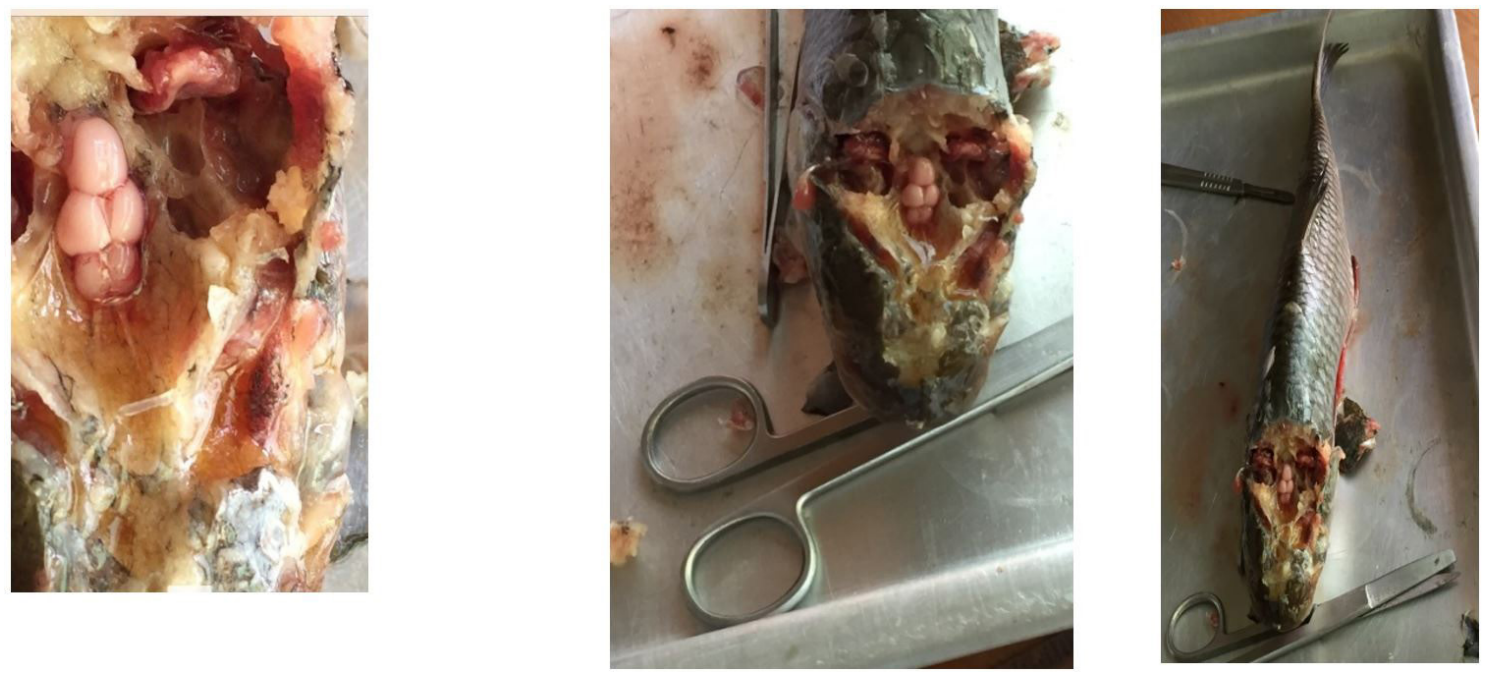

Figure 1. brain of common carps in captive environment.

Table 2. Morphometric measurement of common carp in wild condition.

\begin{tabular}{ccccccc}
\hline Fish specimen & TBW $(\mathbf{g})$ & TBL $(\mathbf{c m})$ & TBW $(\mathbf{c m})$ & HTSL $(\mathbf{c m})$ & ETEL $(\mathbf{c m})$ & BW $(\mathbf{g})$ \\
\hline 1 & 160 & 28 & 5 & 3.9 & 2.2 & 0.39 \\
2 & 140 & 26.5 & 4.5 & 3.5 & 2 & 0.32 \\
3 & 150 & 27 & 4.7 & 3.7 & 4.1 & 0.35 \\
4 & 221 & 28 & 5 & 4.5 & 2.3 & 0.42 \\
5 & 270 & 29 & 5.8 & 4.2 & 2.3 & 0.67 \\
6 & 230 & 28.2 & 5.1 & $3.96 \pm 0.35$ & $2.23 \pm 0.17$ & $0.45 \pm 0.14$ \\
\hline
\end{tabular}

TBW= Total body weight, TBL=Total body length, TBW=Total body width, HTSL=Head to snout length, ETEL=Eye to eye length, BW=Brain weight

Table 3. Comparative analysis of length (head to snout; eye to eye) and brain weight among captive and wild population of common carp

\begin{tabular}{lccc}
\hline Fish specimen & Means of head to snout length $(\mathbf{c m})$ & Means of eye to eye length $(\mathbf{c m})$ & Means of brain weight $(\mathbf{g})$ \\
\hline Wild fishes mean & $3.96 \pm 0.35$ & $2.23 \pm 0.17$ & $0.45 \pm 0.14$ \\
Captive fish mean & $4.91 \pm 1.03$ & $4.13 \pm 0.77$ & $0.28 \pm 0.047$ \\
\hline
\end{tabular}

length was $27.78 \pm 0.89 \mathrm{~cm}$ while the mean value of captive fishes was $33.91 \pm 2.37 \mathrm{~cm}$ thus the total length of wild fishes was found slightly less as compare to captive fishes.

\subsection{Comparative analysis of body weight and brain} weight of common carps in wild and captive environment

The obtained data of different body weight of wild and captive fishes was compare with its brain weight. The current study shows that the means value of body weight $345 \pm 48.68$ of captive fishes was almost greater than wild fishes means values of body weight $195.16 \pm 52.53$. Similarly, the means of brain weight of captive fishes $0.28 \pm 0.047$ was almost less as compare wild fishes 0.45 . Table 5.
Table 4. Comparative analysis regarding total body length of common carps in captive and wild condition

\begin{tabular}{cc}
\hline Fish specimen & $\begin{array}{c}\text { Means of total body length } \\
\text { (cm) }\end{array}$ \\
\hline Wild fish mean & $27.78 \pm 0.89$ \\
Captive means & $33.91 \pm 2.37$ \\
\hline
\end{tabular}

Table 5. Comparative analysis of body weight and brain weight of common carps in wild and captive environment

\begin{tabular}{lcc}
\hline Fishes specimen & Body weight $(\mathrm{g})$ & Brain weight $(\mathrm{g})$ \\
\hline Captive fishes & $345 \pm 48.68$ & $0.28 \pm 0.047$ \\
Wild fishes & $195.16 \pm 52.53$ & $0.45 \pm 0.14$ \\
\hline
\end{tabular}




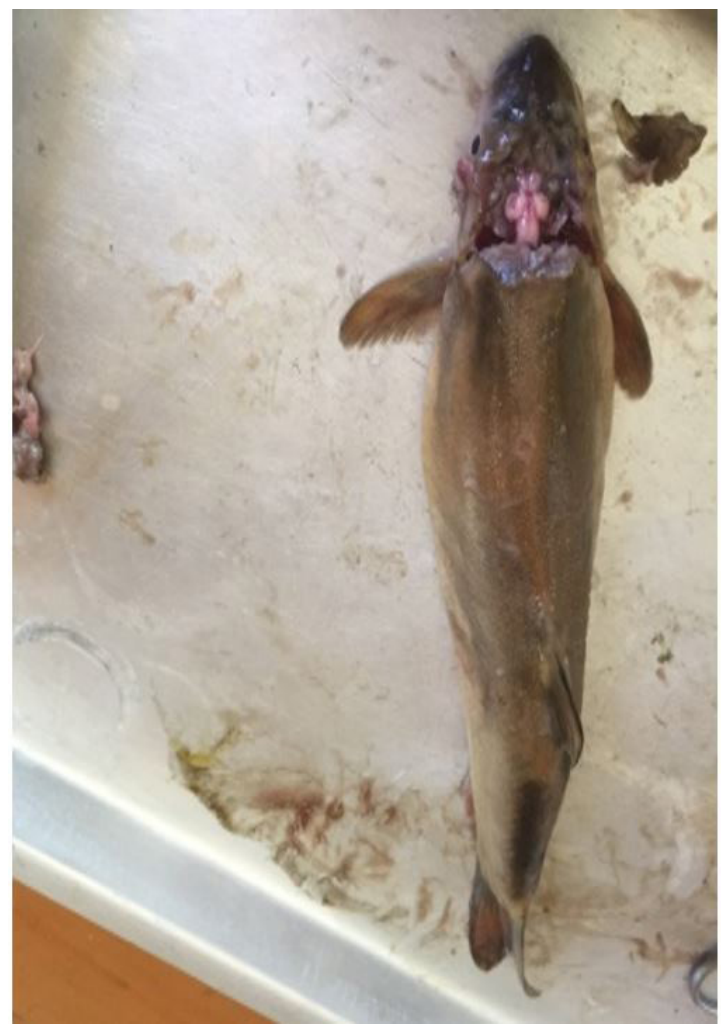

Figure 2. brain of common carps in wild environment.

\section{Discussion}

The current study shows that common carp under captive condition have differences in brain structure as compared to its wild generation. In our study the observation was that fishes grows under captive condition shows considerable reduction in whole brain anatomy and brain weight. Our outcomes suggest that hatchery reared fishes potentially influence the normal development and growth of common carp brain. Still knowledge is required to which know factors are responsible for brain size reduction between wild and captive reared stocks. But anyhow it is assumed that reduction in brain size may be due to the absence of some factors which are externally necessary for hatchery rearing environment.

Visible changes in brain morphology have been observed in salmonid fishes under rearing condition as Näslund et al. (2012), Lema and Nevitt (2003). They carried out their research on rainbow trout between captive and wild population and examined eight brain measure of captive and wild fishes in relation to standard body length, and learn difference in brain measurement. They found that wild fishes have large size by volume in telencephalon and optic lobe as compare to their captive reared individual.

Our result displays closest relation in the case of brain size which is larger in wild fishes while smaller in hatchery reared specimens in relation to their body sizes. Näslund et al. (2016) showed in this study that high density also effects the fishes brain size he reared the fishes in two density condition of hatchery, the fishes with low

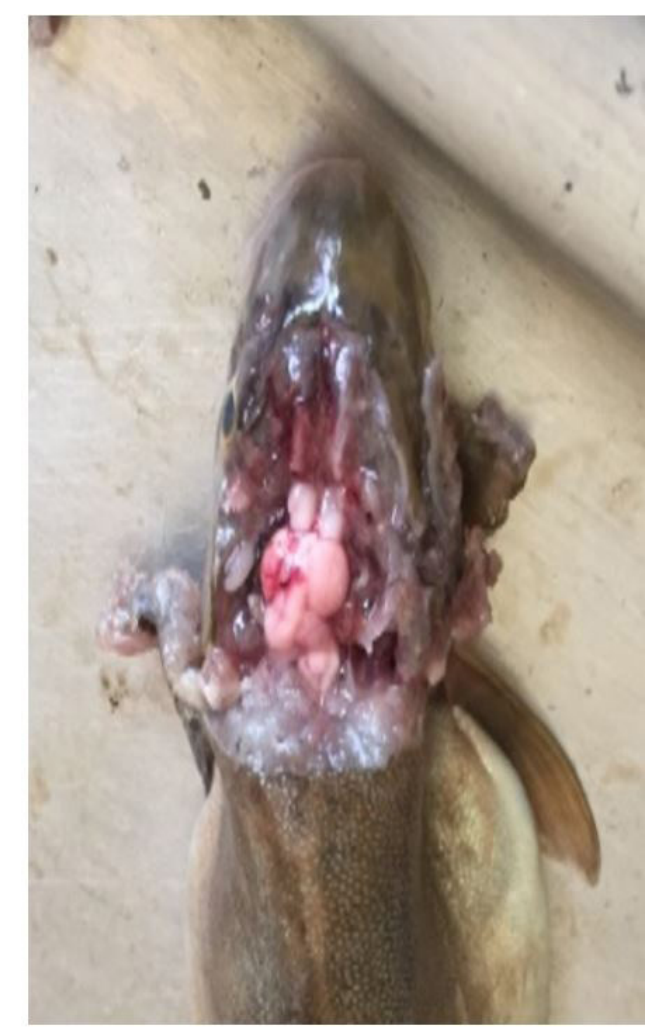

density possess large brain size and high density fish's shows small brain size. Our result show that wild fishes fore brain are large in size as compare to the fore brain of hatchery reared fishes.

Study also shows that development of brain has correlation with environmental complexity and social factor. It is notified by different researchers that environmental factors such as habitat enhancement are correlated with brain size. Therefore, environmental condition also varies among fishes of wild and captive fishes (Kihslinger and Nevitt, 2006) that rainbow trout (Onchorhynchus mykiss) elevated under enriched nature pond exhibit same neural phenotypes as matched to wild condition, those reared in normal condition display small brain size as compared to slightly complex environment. They found cerebella larger in size. So our result is very close to their finding in cerebellum case.

Pollen and Hofmann (2008) conducted their experiment on cichlid they found that increase of fore brain structure such as cerebellum and telencephalon of cichlid fishes shows positive growth rate to environmental condition. Cichlid fishes found in enriched environment condition exhibited greater size of brain morphology as compare to unreached rearing environment. Our study shows in case of cerebellum closest relation with (Pollen and Hofmann, 2008), while oppose in case of telencephalon. The environmental condition affects the brain size it has been evaluated by various researchers from decade and other taxa such as sheep, cats, and rabbits. They evaluated 
that the domesticated animals had smaller brain size (18-33\%) and relation to the size of their body from wild fishes (Kruska., 1998; Burns et al., 2009). Current studies suggested that brain development is correlated with complex environment. They suggested that this development may be due to social interactions.

Burns et al. (2009) worked on guppies whom cultured the fishes under the laboratory condition had smaller brain size compared to their wild generation especially in the case of optic tactum and telencephalon in wild display large size there is no significance differences in other parts. Current experiment display very closest consistencies with Burns et al. (2009) cerebellum have large size in wild specimen in our result. They suggested that it may be due to environmental factors.

Some scientists also suggested that brain development has also influenced by also social factors (Gonda et al., 2013). They display in their research that pond raised matched to fish raised individually, other scientist also conducted their experiment on social factors, Pollen et al. (2008) studied closely related cichlid fish species live in shallow water feeding species display neural architecture different than deep water dweller species.

Current research presents that Cyprinus carpio under captive condition have small brain weight $(\mathrm{g}$ ) relative to their total body weight as compared to its wild population. This study shows significant differences in weight and structure of forebrain like cerebellum optic lobe and length and in relation to standard length while there are little differences in mid brain and hindbrain in captive and wild fishes. It may be due to the missing of those conditions which play important rule in brain development and behaviors'. Current study especially address to restoration sectors to produce more wild types to issue wild types fish having highly survival chance in natural ecological condition.

This was the first attempt we agreed to know the impact of culture condition on neural and behavioral development. Further studies are required to understand more in detail that how the hatchery reared common carp show small brain size than as compared to its wild population and such variance in neural phenotypes can be reimbursed by providing required stimulus enrich environment. Advance culture sector should be established that produce more wild types fishes, because wild types have more chance of survival. According to the rules of IUCN guidelines for restocking to release healthy fishes to wild environment. It is because of ecological, economical, conservational and ethical importance that fishes release to nature having ability to survive in nature. We conducted our experiment on common carp to know influence of hatchery condition on brain development of common carp we found notable in total brain weight in relation to their standard body weight. Further study required at molecular level to know that how hatchery reared common carp exhibit smaller brain size as compared to its wild population.

\section{Acknowledgments}

The author acknowledged the local fishermen and the fish hatchery authorities for their cooperation during specimen collection. The authors extend their appreciation to the researchers supporting project number(RSP-2020/7), King Saud University, Riyadh, Saudi Arabia

\section{References}

AHMAD, A., KHAN, W., DAS, S.N., PAHANWAR, W.A., KHALID, S., MEHMOOD, S.A., AHMED, S., KAMAL, M., AHMED, M.S., HASSAN, H.U., ZAHOOR, S. and MAQBOOL, A., 2020. Assessment of ecto and endo parasites of Schizothorax plagiostomus inhabiting river Panjkora, Khyber Pakhtunkhwa, Pakistan. Brazilian Journal of Biology = Revista Brasileira de Biologia, vol. 81, no. 1, pp. 92-97. http://dx.doi.org/10.1590/1519-6984.222214.

BRANDSTÄTTER, R. and KOTRSCHAL, K., 1990. Brain growth patterns in four European cyprinid fish species (Cyprinidae, Teleostei): roach (Rutilus rutilus), bream (Abramis brama), common carp (Cyprinus carpio) and sabre carp (Pelecus cultratus). Brain, Behavior and Evolution, vol. 35, no. 4, pp. 195-211. http://dx.doi. org/10.1159/000115867. PMid:2379081.

BRANNON, E.L., 1993. The perpetual oversight of hatchery programs. Fisheries Research, vol. 18, no. 1-2, pp. 19-27. http://dx.doi. org/10.1016/0165-7836(93)90037-8

BURNS, J.G., SARAVANAN, A. and HELEN RODD, F., 2009. Rearing environment affects the brain size of guppies: lab-reared guppies have smaller brains than wild-caught guppies. Ethology, vol. 115, no. 2, pp. 122-133. http://dx.doi.org/10.1111/j.1439-0310.2008.01585.x.

CRESPI, V. and NEW, M., 2009. Cultured aquatic species fact sheets. Rome: FAO.

EBINGER, P. and RÖHRS, M., 1995. Volumetric analysis of brain structures, especially of the visual system in wild and domestic turkeys (Meleagris gallopavo). Journal für Hirnforschung, vol. 36, no. 2, pp. 219-228. PMid:7615926.

FLAGG, T.A., BEREJIKIAN, B.A., COLT, J., DICKHOFF, W.W., HARRELL, L.W., MAYNARD, D.J., NASH, C.E., STROM, M.S., IWAMOTO, R.N. and MAHNKEN, C.V., 2000. Ecological and behavioral impacts of artificial production strategies on the abundance of wild salmon populations: a review of practices in the Pacific Northwest. Seattle, WA: National Oceanic and Atmospheric Administration, National Marine Fisheries Service, Northwest Fisheries Science Center.

GONDA, A., HERCZEG, G. and MERILÄ, J., 2013. Evolutionary ecology of intraspecific brain size variation: a review. Ecology and Evolution, vol. 3, no. 8, pp. 2751-2764. http://dx.doi. org/10.1002/ece3.627.

GROSS, M.R., 1998. One species with two biologies: atlantic salmon (Salmo salar) in the wild and in aquaculture. Canadian Journal of Fisheries and Aquatic Sciences, vol. 55, no. S1, pp. 131-144. http://dx.doi.org/10.1139/d98-024.

KHALID, S., KHAN, W., DAS, S.N., AHMAD, A., MEHMOOD, S.A., PAHANWAR, W.A., AHMED, S., KAMAL, M., WAQAS, M., WAQAS, R.M., HASSAN, H.U., ZAHOOR, S. and MAQBOOL, A., 2020. Evaluation of ecto and endo parasitic fauna of Schizothorax plagiostomus inhabitants of river Swat, Khyber PakhtunKhwa, Pakistan. Brazilian Journal of Biology = Revista Brasileira de Biologia, vol. 81, no. 1, pp. 98-104. http://dx.doi. org/10.1590/1519-6984.222215.

KHAN, A.M., ALI, Z., SHELLY, S.Y., AHMAD, Z. and MIRZA, M.R., 2011. Aliens; a catastrophe for native fresh water fish diversity in Pakistan. The Journal of Animal and Plant Sciences, vol. 21, no. 2, pp. 435-440.

KHAN, M.N., SHAHZAD, K., CHATTA, A., SOHAIL, M., PIRIA, M. and TREER, T., 2016. A review of introduction of common carp Cyprinus carpio in Pakistan: origin, purpose, impact and management. Ribarstvo, vol. 74, no. 2, pp. 71-80. http://dx.doi. org/10.1515/cjf-2016-0016. 
KIHSLINGER, R.L. and NEVITT, G.A., 2006. Early rearing environment impacts cerebellar growth in juvenile salmon. The Journal of Experimental Biology, vol. 209, no. 3, pp. 504-509. http://dx.doi. org/10.1242/jeb.02019. PMid:16424100.

KOTRSCHAL, K. and PALZENBERGER, M., 1992. Neuroecology of cyprinids: comparative, quantitative histology reveals diverse brain patterns. Environmental biology of European Cyprinids, vol. 33, pp. 135-152. http://dx.doi.org/10.1007/978-94-0112544-4_13.

KOTRSCHAL, K., VAN STAADEN, M.J. and HUBER, R., 1998. Fish brains: evolution and anvironmental relationships. Reviews in Fish Biology and Fisheries, vol. 8, no. 4, pp. 373-408. http:// dx.doi.org/10.1023/A:1008839605380.

KRUSKA, D., 1996. The effect of domestication on brain size and composition in the mink (Mustela vison). Journal of Zoology, vol. 239, no. 4, pp. 645-661. http://dx.doi. org/10.1111/j.1469-7998.1996.tb05468.x.

LEMA, S.C. and NEVITT, G.A., 2004. Evidence that thyroid hormone induces olfactory cellular proliferation in salmon during a sensitive period for imprinting. The Journal of Experimental Biology, vol.207, no. 19, pp. 3317-3327. http://dx.doi.org/10.1242/ jeb.01143. PMid:15326208.

MARCHETTI, M.P. and NEVITT, G.A., 2003. Effects of hatchery rearing on brain structures of rainbow trout, Oncorhynchus mykiss. Environmental Biology of Fishes, vol. 66, no. 1, pp. 9-14. http:// dx.doi.org/10.1023/A:1023269221678.
MASAI, H., TAKATSUJI, K., SATO, Y. and OJIMA, Y., 1983. Morphological variation in crucian brains, with special reference to the origin of the goldfish. Journal of Zoological Systematics and Evolutionary Research, vol. 20, no. 4, pp. 296-301. http://dx.doi. org/10.1111/j.1439-0469.1983.tb00555.x.

MAYNARD, D.J., RILEY, S., BEREJIKIAN, B.A. and FLAGG, T.A. 2003. Development of a Natural Rearing System to Improve Supplemental Fish Quality. Portland, OR: Bonneville Power Administration, pp. 1-188. http://dx.doi.org/10.2172/815122.

MIRZA, M.R. and SANDHU, A.A., 2007. Fishes of the Punjab Pakistan. Lahore: Polymer Publication, Urdu Bazar.

NÄSLUND, J., AARESTRUP, K., THOMASSEN, S.T. and JOHNSSON, J.I., 2012. Early enrichment effects on brain development in hatchery-reared Atlantic salmon (Salmo salar): no evidence for a critical period. Canadian Journal of Fisheries and Aquatic Sciences, vol. 69, no. 9, pp. 1481-1490. http://dx.doi.org/10.1139/ f2012-074.

NÄSLUND, J., LARSEN, M.H., THOMASSEN, S.T., AARESTRUP, K. and JOHNSSON, J.I., 2017. Environment-dependent plasticity and ontogenetic changes in the brain of hatchery-reared Atlantic salmon. Journal of Zoology, vol. 301, no. 1, pp. 75-82. http:// dx.doi.org/10.1111/jzo.12392.

POLLEN, A.A. and HOFMANN, H.A., 2008. Beyond neuroanatomy: novel approaches to studying brain evolution. Brain, Behavior and Evolution, vol. 72, no. 2, pp. 145-158. http://dx.doi. org/10.1159/000151474. PMid:18836260. 